\title{
Analysis of transient stability in power systems with multiple shunt and series compensators
}

\section{Çoklu seri ve paralel kompanzatörler ile güç sistemlerinde geçici kararlılık analizi}

\author{
Mehmet Kenan DÖŞOĞLU ${ }^{*}$ \\ 1Department of Electrical-Electronics Engineering, Technology Faculty, Duzce University, Duzce, Turkey. \\ kenandosoglu@duzce.edu.tr
}

Received/Geliş Tarihi: 01.02.2016, Accepted/Kabul Tarihi: 28.05.2016

* Corresponding author/Yazıșilan Yazar

doi: $10.5505 /$ pajes.2016.68916 Research Article/Araștırma Makalesi

\begin{abstract}
This study investigates the effect of multiple shunt and series compensators in transient stability case of a multi-machines power system. 22 bus multi machine real systems are modeled with Static Synchronous Compensator (STATCOM) and Static Synchronous Series Compensator (SSSC). The locations of the compensators are identified depending on the weak buses and transmission lines with highest voltage dip during transient cases. Transient stability cases are examined without STATCOM and SSSC, with STATCOM and SSSC multiple STATCOM and SSSC. Besides, Angular speeds of synchronous generators and variations voltage of buses are examined. Oscillations can decrease within short time with multiple STATCOM and SSSC in transient instability case.
\end{abstract}

Keywords: Transient stability, STATCOM, SSSC, Multi-Machines system

\section{Introduction}

Power systems are very complex due to their interconnected structure. There may exist local, small scale problems in power systems as well as disruptive, system wide problems. System transients, inter-area oscillations and voltage collapses may be considered as examples of large scale problems. Flexible AC Transmission System (FACTS) controllers are developed and being utilized for a fast and flexible control to deal with those problems. With the advances in power electronics, voltage source inverter (VSI) based FACTS devices have shown better performance than other control devices. Primary VSI based controllers include shunt connected Static Synchronous Compensator (STATCOM), Static Synchronous Series Compensator (SSSC), and Unified Power Flow Controller (UPFC).

Many studies have been carried out on modeling and control schemes of FACTS controllers. Voltage regulation and rotor angle stability have been studied based on various critical clearing time and loading conditions [1-5]. Design and nonlinear coordinate controller for a STATCOM installed in infinite bus power system, and it shows that the proposed controller provides not only a coordinated control of ac-dc bus voltage but also good damping under transient conditions [6]. STATCOM modeling for voltage and angle stability studies has been given in [7]. The effect of control mode of SSSC, one of the inverter based FACTS, has been investigated in [8] and shown that SSSC operated in the permanent reactance control results in higher power oscillation damping, and synchronizing power limit than constant voltage mode. Similar results were
Öz

Bu çalıșmada cok baralı bir güc sisteminin geçici kararllık durumunda çoklu seri ve parallel kompanzatörlerin etkileri incelenmiștir. 22 bara çok makinalı gerçek sistemin Statik Senkron Kompazatör (STATCOM) ve Statik Senkron Seri Kompanzatör (SSSC) ile modellemesi yapılmıștır. Kompanzatörlerin yerleșimi geçici durum esnasinda hatlardaki en yüksek gerilim düșümüne ve zayıf baraya bağlı olarak belirlenmiștir. Geçici kararlılı durumu STATCOM and SSSC olmadığ durum, STATCOM and SSSC olduğu durum ve STATCOM and SSSC çoklu olduğu durumda incelenmiștir. Bunu yanısıra baraların gerilim değișimleri ve senkron generatorlerin açısal hız değișimleri incelenmiștir. Coklu STATCOM and SSSC kullanımı ile geçici kararsızlık durumunda kısa zaman içerisinde salınımların azaldığı görülmüștür.

Anahtar kelimeler: Geçici kararlılık, STATCOM, SSSC, Cok-Makinalı sistem

obtained in [9-10] in which the optimal control schemes are presented for dynamic series compensation and voltage regulation. It has been shown that SSSC is effective in improving rotor angle stability in infinite bus system and multi machine power systems [11]. Some of the studies dealing with series and shunt connected FACTS devices together are as follows: Dynamic operation of STATCOM and SSSC under various load excursions have been investigated in [12-13]. They are employed in analyzing steady-state and transient stability in an infinite bus system. While STATCOM provides voltage support, depending on the SSSC operation of control mode, they both are good at damping oscillations [14-19]. Application of STATCOM and SSSC on damping inter area oscillations are shown [20]. Optimal locations of various FACTS devices have been determined by using trajectory sensitivity analysis (TSA) [21]. A method is proposed to evaluate first swing stability of a large power system in the presence of FACTS [22]. A 20 machine system has been tested by observing machine angles and active reactive power changes. Another study conducted shows the impact of various FACTS devices on improving angle stability in the case of local and inter area oscillations [23].

This study examines the impact of multiple FACTS devices on a large power system. After a brief introduction of modeling of a multi-machine power system with FACTS devices, a procedure for transient stability analysis of a system with multiple FACTS devices is given. A multi-machine 22 bus system is used for this purpose. Various responses of the system against a three phase fault are analyzed and compared for cases with no device, single device and multi devices. The simulation studies show that the presence of multiple 
STATCOM provides more damping for oscillations than multiple SSSC.

\section{Modelling of multimachine power system}

Before adding controllers to the system, $n_{g}$ machine, $n$ buspower system is modeled where machines are represented by a conventional model. The swing equations are shown as follows $\left(i=n+1, n+n_{g}\right)[24]$.

$\frac{d \delta_{i}}{d t}=w_{s} \Delta w_{r_{i}}$
$2 H_{i} \frac{d \Delta W_{r_{i}}}{d t}=P_{m_{i}}-\sum_{j=1}^{n+n g}\left|V_{i}\right| \times\left|V_{j}\right| \times\left[\begin{array}{l}G_{i j} \cos \left(\delta_{i}-\delta_{j}\right) \\ +B_{i j} \sin \left(\delta_{i}-\delta_{j}\right)\end{array}\right]-K D_{i} \Delta w_{r_{i}}$

The power flow equations are given depending on algebraic equations $(i=1 \ldots \ldots \ldots n)$;

$$
\begin{gathered}
P L_{i}=\sum_{j=1}^{n}\left|V_{i}\right| \times\left|V_{j}\right| \times\left|Y_{i j}\right| \times \cos \left(\delta_{i}-\delta_{j}-\theta_{i j}\right) \\
2 H_{i} \frac{d \Delta W_{r_{i}}}{d t}=P_{m_{i}}-\sum_{j=1}^{n+n g}\left|V_{i}\right| \times\left|V_{j}\right| \times\left[\begin{array}{l}
G_{i j} \cos \left(\delta_{i}-\delta_{j}\right) \\
+B_{i j} \sin \left(\delta_{i}-\delta_{j}\right)
\end{array}\right]-K D_{i} \Delta W_{r_{i}}
\end{gathered}
$$

Where $Y_{i j}=\left|Y_{i j}\right| / \theta_{i j}$ obtained from the augmented $Y_{B U S}$ matrix where the admittance corresponding to the transient reactance of the machines are included $P L_{i}$ and $Q L_{i}$ are the real and reactive power loads, respectively, at the $i^{\text {th }}$ bus [25[27].

\section{Modelling of multiple STATCOM and SSSC}

As shown in Figure 1, the STATCOM is connected in parallel with Bus $i$, while the SSSC is connected in series between Bus $i$ and Bus $\mathrm{j}$. They both consist of a voltage source converter connected by a coupling transformer to the system, therefore modelled as a controllable voltage source series with a leakage reactance excluding ohmic losses. By adjusting voltage, the reactive power can be controlled. The expressions for the current, reactive power injection, voltage and DC link voltage are given as,

$$
\begin{gathered}
I_{s}=\frac{V_{s}-V_{b u s}}{j X_{1}} \\
Q_{s}=V_{b u s}^{2} \frac{V_{s} / V_{b u s}-1}{X_{1}} \\
V_{\text {inj }}=m \times k \times V_{d c}(\cos \delta-j \sin \delta) \\
I_{s}=I_{d}+j I_{q} \\
\frac{m \times k}{d t}=\frac{m \times V_{d c}}{C_{d c}}\left(I_{d} \cos \delta+I_{q} \sin \delta\right)
\end{gathered}
$$

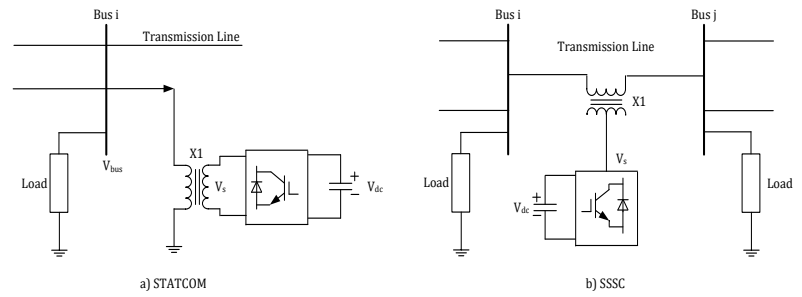

Figure 1: The STATCOM and SSSC circuit.

The active power equations with STATCOM connected to bus i can be given below:

$$
\begin{aligned}
& P_{i}=P+\sum_{j=1}^{N}\left[V_{i}\right] \times\left[V_{j}\right] \times\left[Y_{k j}\right] \times \cos \left(\delta_{k}-\delta_{j}-\theta_{k j}\right) \\
& Q_{i}=Q+\sum_{j=1}^{N}\left[V_{i}\right] \times\left[V_{j}\right] \times\left[Y_{k j}\right] \times \sin \left(\delta_{k}-\delta_{j}-\theta_{k j}\right)
\end{aligned}
$$

Where active power $(P)$ and reactive power $(Q)$ are found to be:

$$
\begin{aligned}
& P=G \times\left[V_{k}\right]^{2}-\left[V_{k}\right] \times[E] \times[Y] \times \cos \left(\delta_{k}-\delta_{j}-\theta\right) \\
& Q=-G \times\left[V_{k}\right]^{2}-\left[V_{k}\right] \times[E] \times[Y] \times \sin \left(\delta_{k}-\delta_{j}-\theta\right)
\end{aligned}
$$

Active and reactive power equations for SSSC can be stated as follows:

$$
\begin{gathered}
P_{i}=P_{i j}+\sum_{k=1}^{N}\left[V_{i}\right] \times\left[V_{k}\right] \times\left[Y_{i k}\right] \times \cos \left(\delta_{i}-\delta_{k}-\theta_{i k}\right) \\
Q_{i}=Q_{i j}+\sum_{k=1}^{N}\left[V_{i}\right] \times\left[V_{k}\right] \times\left[Y_{i k}\right] \times \sin \left(\delta_{i}-\delta_{k}-\theta_{i k}\right) \\
P_{j}=P_{j i}+\sum_{k=1}^{N}\left[V_{j}\right] \times\left[V_{k}\right] \times\left[Y_{j k}\right] \times \cos \left(\delta_{j}-\delta_{k}-\theta_{j k}\right) \\
Q_{j}=Q_{j i}+\sum_{k=1}^{N}\left[V_{j}\right] \times\left[V_{k}\right] \times\left[Y_{j k}\right] \times \sin \left(\delta_{j}-\delta_{k}-\theta_{j k}\right)
\end{gathered}
$$

Dynamic equations for STATCOM and SSSC can be expressed as follows:

$$
\begin{aligned}
& \frac{d I_{d}}{d t}=\frac{-R}{L} \times I_{d}+W \times I_{p}-\frac{1}{L} \times V_{d}+\frac{1}{L} \times E_{d}=0 \\
& \frac{d V_{C}}{d t}=\frac{-3}{2 C_{d c}}\left(m_{q} \times I_{q}+m_{d} \times I_{d}\right)=0 \\
& \left|\begin{array}{c}
I_{q} \\
I_{d}
\end{array}\right|=\left[\begin{array}{l}
-R \ldots \ldots-L W \\
L W \ldots . . .-R
\end{array}\right]^{-1} \times\left[\begin{array}{c}
V_{q} \\
V_{d}
\end{array}\right]-\left[\begin{array}{l}
-R \ldots \ldots-L W \\
L W \ldots . . .-R
\end{array}\right]^{-1} \times\left[\begin{array}{l}
E_{q} \\
E_{d}
\end{array}\right] \\
& I_{q d}=Y_{q d} \times V_{q d}+I_{q d} \times E
\end{aligned}
$$

Where, $\Delta w r$ per unit speed deviation, $H$ inertia constant, $w_{S}$ synchronous generator speed, $P_{m}$ mechanical power input in per unit, $\delta_{i}$ the angular positions of the rotors, $P L_{i}$ real power 
loads, $Q L_{i}$ reactive power loads, $X_{1}$ leakage reactance of the coupling transformer, $m$ modulation index, $V_{d c}$ DC link voltage, $I_{d}$ park transformation real line current, $I_{q}$ park transformation reactive line current, $Y$ admittance. Multiple STATCOM and SSSC are considered here as controllers. Admittance matrix $\left(Y_{t}\right)$ given in equation 20 represents a general form of admittances having STATCOM connection in

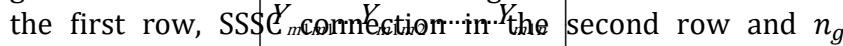

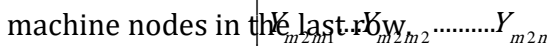

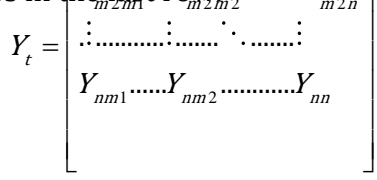

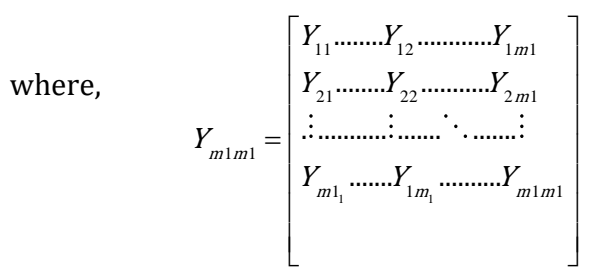

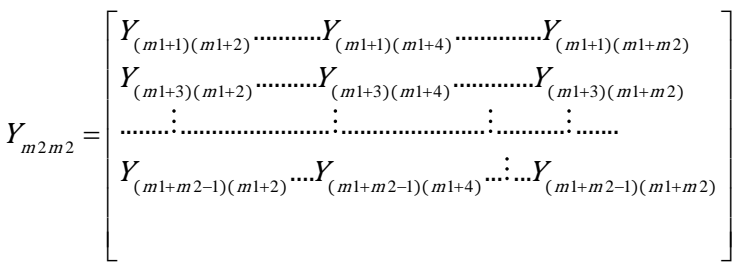

As can be seen from the matrices, diagonal elements $\left(Y_{m 1 m 1}, Y_{m 2 m 2}\right)$ are the elements affected by the installation of the FACTS devices [28]. For the stability analysis, in synchronous generator the sixth order model is used. The equations can be written as,

$$
\begin{gathered}
\delta=f_{b}(\omega-1) \\
\omega=\left(P_{m}-P_{e}-D(\omega-1)\right) / M \\
\left.e_{q}^{\prime}=-e_{q}^{\prime}-\left(x_{d}-x_{d}^{\prime}-\frac{T_{d 0}^{\prime \prime}}{T_{d 0}^{\prime}} \frac{x_{d}^{\prime \prime}}{x_{d}^{\prime}}\left(x_{d}-x_{d}^{\prime}\right)\right) i_{d}+\left(1-\frac{T_{A A}}{T_{d 0}^{\prime}}\right) v_{f}^{*}\right) / T_{d 0}^{\prime} \\
e_{d}^{\prime}=\left(-f_{s}\left(e_{d}^{\prime}\right)+\left(x_{q}-x_{q}^{\prime}-\frac{T_{q 0}^{\prime \prime}}{T_{q 0}^{\prime}} \frac{x_{q}^{\prime \prime}}{x_{q}^{\prime}}\left(x_{q}-x_{q}^{\prime}\right)\right) i_{q}\right) / T_{q 0}^{\prime} \\
e_{q}^{\prime \prime}=\left(-e_{q}^{\prime \prime}+e_{q}^{\prime}-\left(x_{d}^{\prime}-x_{d}^{\prime \prime}+\frac{T_{d 0}^{\prime \prime}}{T_{d 0}^{\prime}} \frac{x_{d}^{\prime \prime}}{x_{d}^{\prime}}\left(x_{d}-x_{d}^{\prime}\right)\right) i_{d}+\frac{T_{A A}}{T_{d 0}^{\prime}} v_{f}^{*}\right) / T_{d 0}^{\prime \prime} \\
e_{d}^{\prime \prime}=\left(-e_{d}^{\prime \prime}+e_{d}^{\prime}+\left(x_{q}^{\prime}-x_{q}^{\prime \prime}+\frac{T_{q 0}^{\prime \prime}}{T_{q 0}^{\prime}} \frac{x_{q}^{\prime \prime}}{x_{q}^{\prime}}\left(x_{q}-x_{q}^{\prime}\right)\right) i_{q}\right) / T_{q 0}^{\prime}
\end{gathered}
$$

Where $f_{b}$ is the fundamental frequency base, $P_{m}$ the mechanical power, $M$ the mechanical starting time, $D$ the damping coefficient, $x_{d}$ and $x_{q}$ the $\mathrm{d}-\mathrm{q}$ axes synchronous reactance, $x^{\prime}{ }_{d}$ and $x^{\prime}{ }_{q}$ the $\mathrm{d}$-q axes transient reactance, $x^{\prime \prime}{ }_{d}$ and $x^{\prime \prime}{ }_{q}$ the d-q axes sub transient reactance, $T^{\prime}{ }_{d 0}$ and $T^{\prime}{ }_{q 0}$ the d-q axes open circuit transient time constant, $T^{\prime \prime}{ }_{d 0}$ and $T^{\prime \prime}{ }_{q 0} \mathrm{~d}-\mathrm{q}$ axes open circuit sub transient time constant, $T_{A A} \mathrm{~d}$-axis additional leakage time constant, $i_{d}$ and $i_{q} \mathrm{~d}$-q axes current, $\delta$ the rotor angle, $w$ the rotor speed, $v_{f}$ the field voltage, $e^{\prime}{ }_{d}$ and $e^{\prime}{ }_{q} \mathrm{~d}-\mathrm{q}$ axes transient voltage, $e^{\prime \prime}{ }_{d}$ and $e^{\prime \prime}{ }_{q} \mathrm{~d}-\mathrm{q}$ axes sub transient voltage [29].

\section{Analysis approach}

The load flow analysis is required for transient stability analyses. The results of the load flow are important for making decision in applying fault and determining the location of the compensators. The following steps are considered in analyzing transient stability effects of the system with multi compensators.

Level 1) Perform load flow,

Level 2) List the buses from the lowest voltage to the highest voltage based on the load flow results,

Level 3) List the lines according to their voltage drop, from the highest to the lowest based on the load flow results,

Level 4) Perform fault analysis by creating a three phase fault on the bus with the lowest voltage to show the severe impact,

Level 5) Locate a shunt compensator on the bus with the second lowest voltage,

Level 6) Locate a series compensator between the bus with the second lowest voltage and the neighboring bus, seeking that the highest voltage drop exists on the lines between those buses,

Level 7) Locate other shunt compensators on the buses according to the bus list determined in Level 2 and Level 5 ,

Level 8) Locate other series compensators between buses according to the line list given in Level 3 and Level 6 .

\section{Simulation study}

The simulation study of a real based multi generator has been shown in Figure 2. In a real based multi generator 14 load buses and 7 generator buses take place [30].

Owing to continuous power flow, while Bus 8 was determined as the lowest voltage, the lines between buses 5-7 and 9-17 buses 9-17 were determined as highest two voltage dips. A three phase fault occurs between the time period of $0.2 \mathrm{~s}$ and $0.35 \mathrm{~s}$. Breakers are placed between buses 7 and 8 .

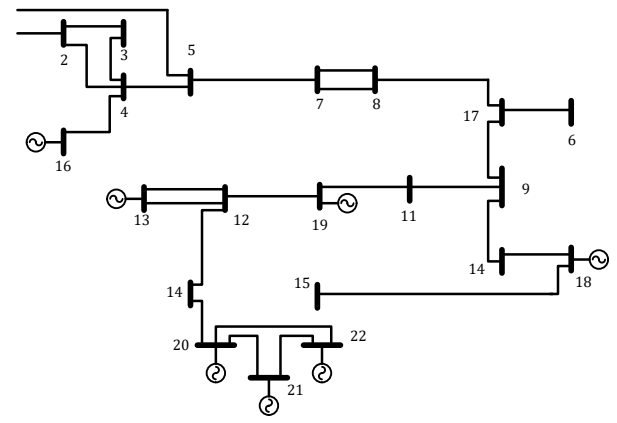

Figure 2: 7 machine 22 bus system.

Circuit breakers located at buses 7 and 8 have been set to open at 5 cycles. 
Without STATCOM and SSSC, with STATCOM and SSSC, multiple STATCOM and SSSC in the faulted system are analyzed. Scenarios studied are given below:

1. A single shunt FACTS , A 100MVA STATCOM at bus 5,

2. A single series FACTS, A 100MVA SSSC between buses 5 and 7 ,

3. Multiple shunt FACTS, A 100MVA STATCOM at bus 5 and a 100MVA STATCOM at bus 7,

4. Multiple series FACTS, A 100MVA SSSC between buses 5-7 and a 100MVA SSSC between buses 9-17.

\section{Simulation results}

After the weakest bus is determined in the system, a three phase fault is created at that bus. The variation of angle, angular speed, active- reactive power of generators and load bus voltages are shown in Figure 3 and Figure 4, when there is no compensator connected to the system.

As can be seen from those figures, angular speed of some machines show unstable behavior without any controller. Bus voltages are not recovered after the fault is cleared. In order to recover the stability of the system, first single STATCOM and SSSC later, multi STATCOM and SSSC are integrated into the system as explained before. Results obtained from analyses of the system with single vs. multiple STATCOM and SSSC are given in Figure 3 to Figure12,

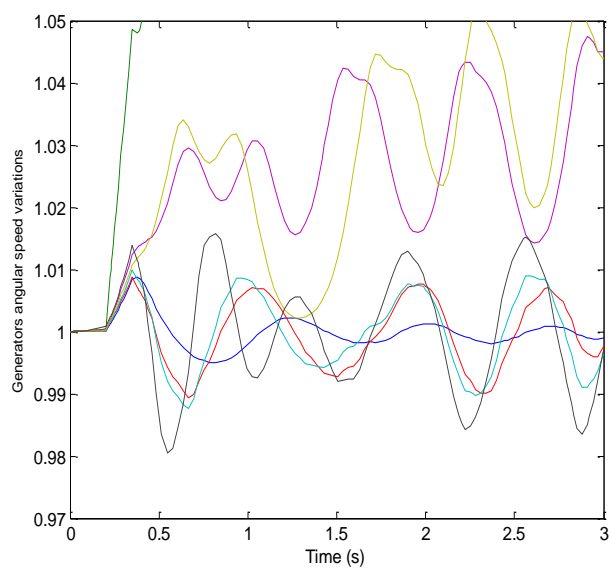

Figure 3: Variations of angular speed without FACTS.

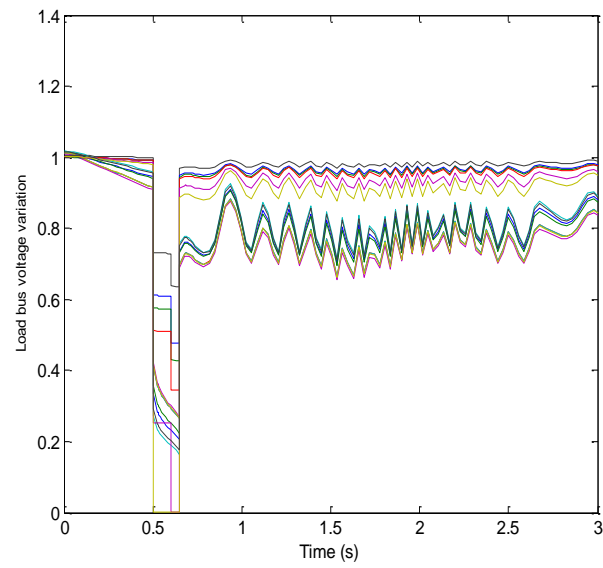

Figure 4: Variations of bus voltage without FACTS.

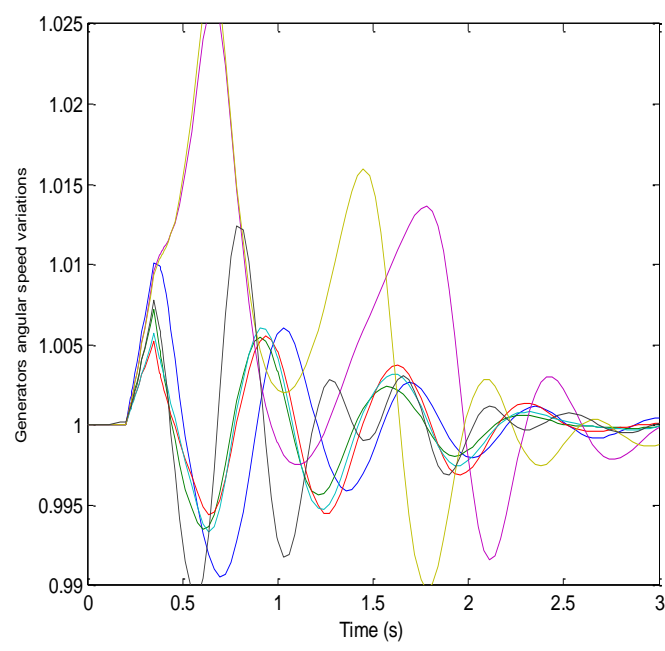

Figure 5: Variations of angular speed with single SSSC.

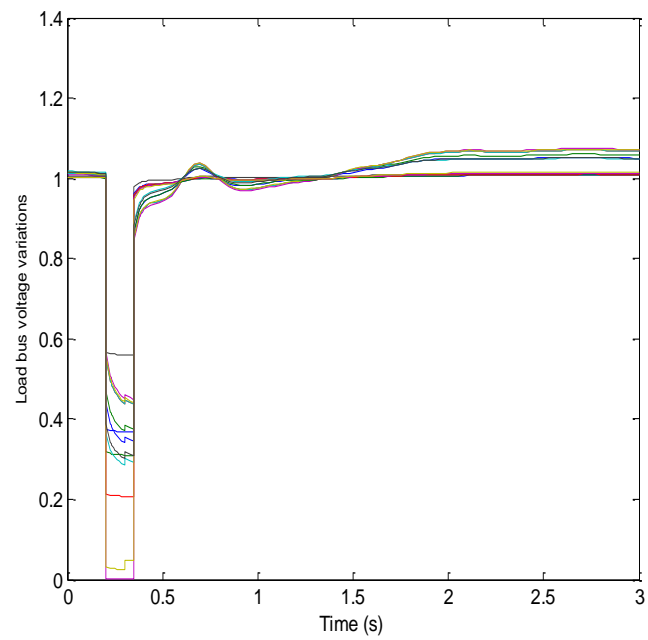

Figure 6: Variations of bus voltage with single SSSC.

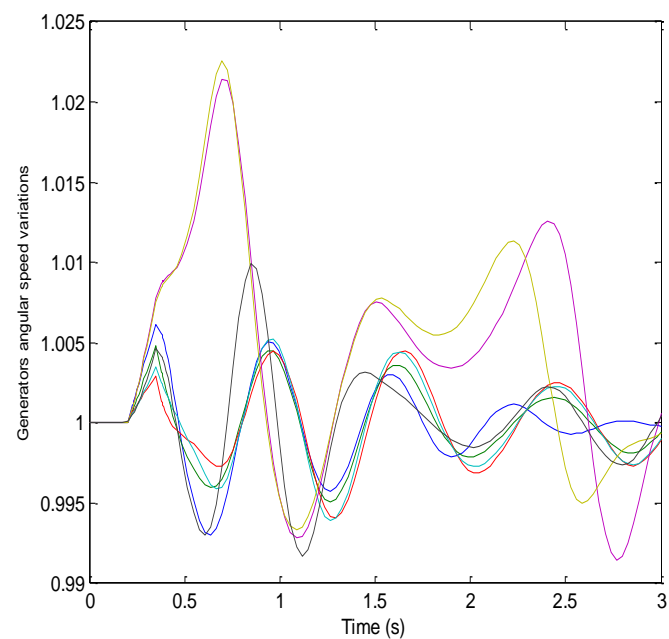

Figure 7: Variations of angular speed with single STATCOM. 


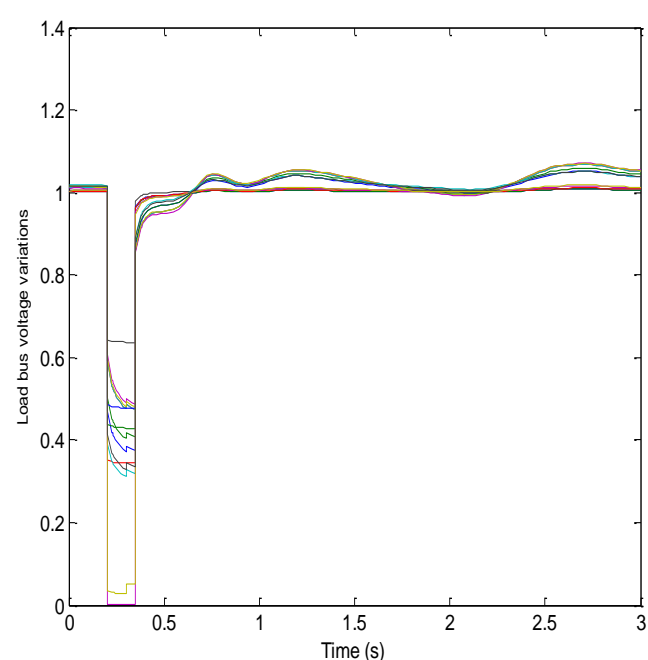

Figure 8: Variations of bus voltage with single STATCOM.

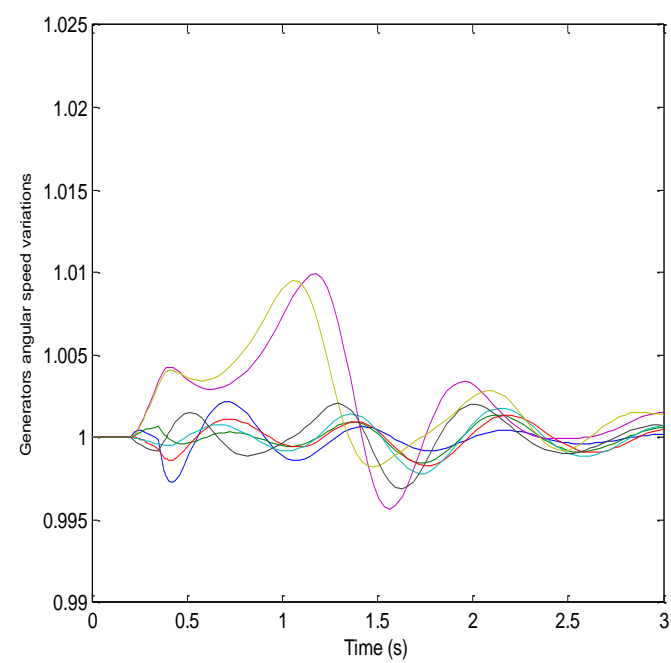

Figure 9: Variations of angular speed with multiple SSSC.

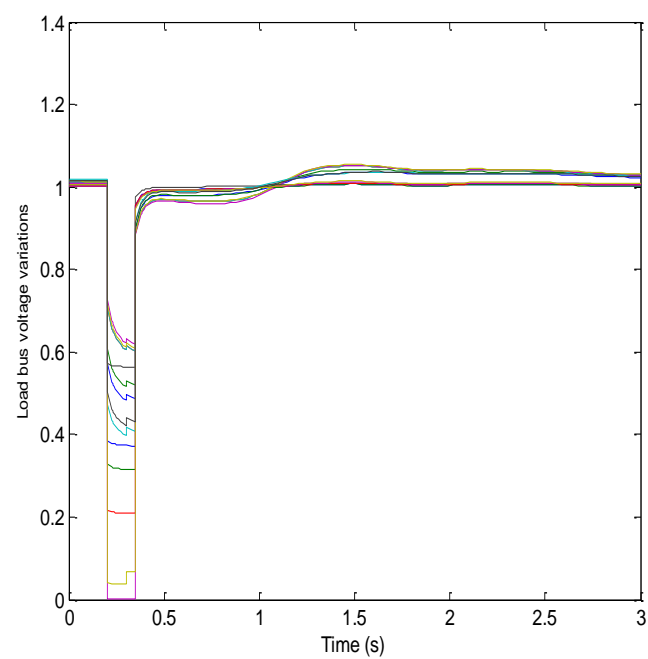

Figure 10: Variations of bus voltage with multiple SSSC.

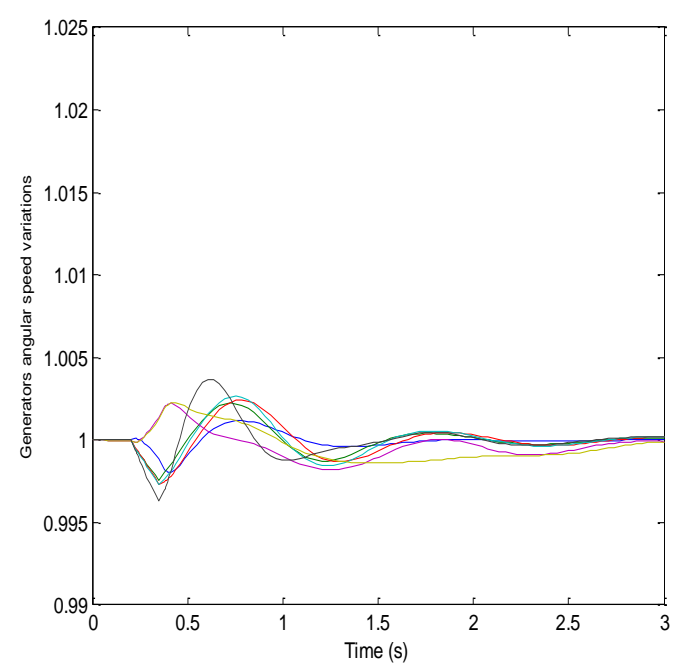

Figure 11: Variations of angular speed with multiple STATCOM.

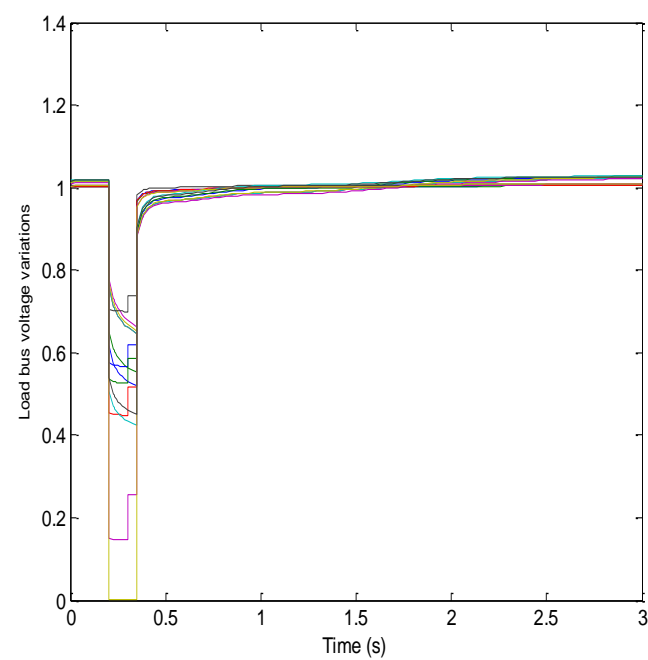

Figure 12: Variations of bus voltage with multiple STATCOM.

The following remarks can be drawn from the simulation results shown in Figure 5 to Figure 12.

1. Adding single compensators into the system can make the system more stable,

2. Oscillations in angular speed, angle and power variations are damped in the system with single STATCOM and SSSC,

3. A 100 MVA SSSC can improve the system stability, but its response is late when compared to a single STATCOM case,

4. Multi STATCOM case is more effective than the multi SSSC case in angle stability and in damping active power oscillations,

5. Having multi compensator integrated into the system has resulted in stability in a shorter time.

Generator angular speed and bus voltage without STATCOM were stabilized in nearly 5 seconds and 3.4 seconds after 3 phase fault, respectively. 
Generator angular speed and bus voltage with STATCOM were stabilized in nearly 3.1 seconds and 3 seconds after 3 phase fault, respectively. Generator angular speed and bus voltage with multi-STATCOM were stabilized in nearly 2.6 seconds and 1 second after 3 phase fault, respectively. Generator angular speed and bus voltage without SSSC were stabilized in nearly 5 seconds and 3.4 seconds after 3 phase fault, respectively.

Generator angular speed and bus voltage with SSSC were stabilized in nearly 3.2 seconds and 2.2 seconds after 3 phase fault, respectively. Generator angular speed and bus voltage with multi-SSSC were stabilized in nearly 2.9 seconds and 1.5 seconds after 3 phase fault, respectively.

While time responses of the variables are shown in Table 1, System parameter values are shown in Table 2 . When there is no compensator in the system, the system reaches the stable mode in a long period of time depending on the excitation control of the machines. The best time response is achieved with the multiple STATCOM case.

Table 1: Time response of the variables.

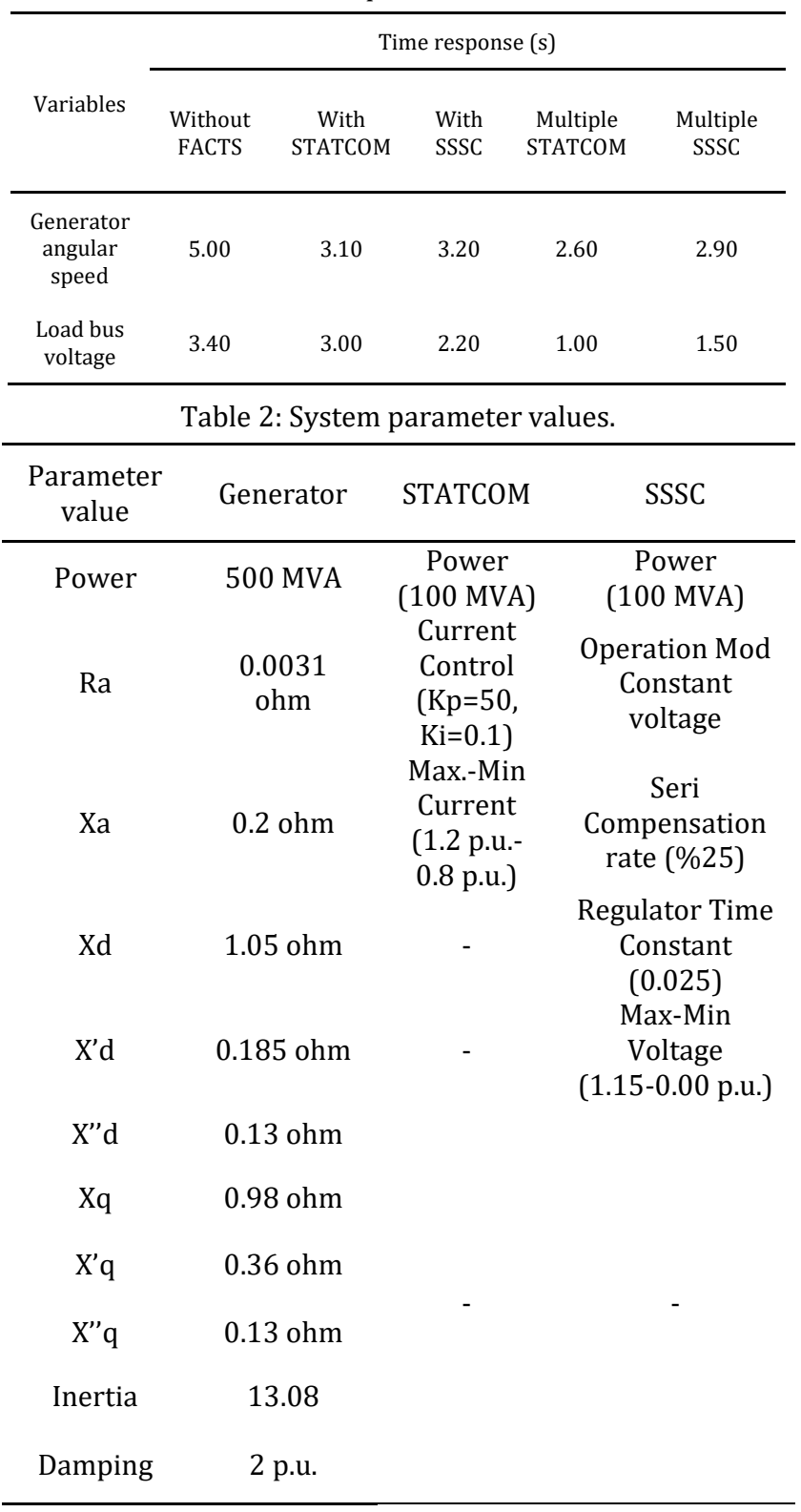

\section{Conclusion}

This study aims to examine the effect of multiple controllers on transient stability of a multi machine power system. Shunt and series controllers are connected to a real based 7 machine- 22 bus system. A procedure for locating shunt and series compensators is explored in this study. Effects of those controllers on the system parameters are observed under transient conditions. System parameters are selected to be generator angular speed and bus voltages. While some machines in the system show unstable behavior with no compensator, the system stability is maintained with controllers' action. Oscillations are damped with the use of single STATCOM and SSSC easily, but it is achieved in a longer time of period causing unreliable energy usage. The utilization of multi compensators is, however, more effective in making the system stable in a shorter time. Another conclusion drawn from this study is that the system with multi STATCOM shows better time response than the system with multi SSSC in damping oscillations.

\section{References}

[1] Leung JSK, Hill DJ, Ni Y. "Global power system control using generator excitation, PSS, FACTS devices and capacitor switching". Electrical Power and Energy Systems, 27(5-6), 448-464, 2005.

[2] Abido MA. "Analysis and assessment of STATCOM-Based damping stabilizers for power system stability enhancement". Electric Power Systems Research, 73(2), 177-185, 2005

[3] Abd-Elazim SM, Ali ES. "Optimal location of STATCOM in multimachine power system for increasing loadability by Cuckoo Search algorithm". International Journal of Electrical Power \& Energy Systems, 80, 240-251, 2016.

[4] Jain T, Sri Niwas S, Suresh CS. Static Compensators (STATCOMs) in Power Systems. Singapore, Springer, 2015.

[5] Ramirez-Gonzalez M, Castellanos-Bustamante R, Calderon-Guizar JG. Malik OP. "Coordinated design of fuzzy supplementary controllers for generator and STATCOM voltage regulators using bat algorithm optimization". International Transactions on Electrical Energy Systems, 26(9), 1847-1862, 2016.

[6] Sahoo NC, Panigrahi BK, Dash PK, Panda G. "Multivariable nonlinear control of STATCOM for synchronous generator stabilization". Electrical Power and Energy Systems, 26(1), 37-48, 2004.

[7] Canizares CA, Pozzi M, Corsi S, Uzunovic E. "STATCOM modeling for voltage and angle stability studies". Electrical Power and Energy Systems, 25(6), 431-441, 2003.

[8] Jowder FAL. "Influence of mode of operation of the SSSC on the Small Disturbance and Transient Stability of a Radial Power System". IEEE Transaction on Power Systems, 20(2), 935-942, 2005.

[9] Moursi ME, Sharaf AM, Arroudi KE. "Optimal control schemes for SSSC for dynamic series compensation". Electric Power Systems Research, 78(4), 646-656, 2008.

[10] Shakarami MR, Kazemi A. "Evaluation of different options for SSSC-based stabilizer to improve damping inter-area oscillations in a multi-machine power system". International Review of Electrical Engineering, 4(6), 1336-1346, 2009. 
[11] Panda S, Swain SC, Rautray PK, Malik RK, Panda G. "Design and analysis of SSSC-based supplementary damping controller". Simulation Modeling Practice and Theory, 18(9), 1199-1213, 2010.

[12] Norouzi AH, Sharaf AM. "Two control schemes to enhance the dynamic performance of the STATCOM and SSSC". IEEE Transaction on Power Delivery, 20(1), 435-442, 2005.

[13] Moursi MSE, Sharaf AM. "Novel reactive power controllers for the STATCOM and SSSC". Electric Power Systems Research, 76(4), 228-241, 2006.

[14] Jowder FAL. "Improvement of synchronizing power and damping power by means of SSSC and STATCOM a comparative study". Electric Power Systems Research, 77(8), 1112-1117, 2007.

[15] Haque MH. "Damping improvement by FACTS Devices: A comparison between STATCOM and SSSC". Electric Power Systems Research, 76(9-10), 865-872, 2006.

[16] Rahimzadeh S, Bina MT, Viki AH. "Steady state model of STATCOM and SSSC using averaging technique". International Review of Electrical Engineering, 4(6), 1391-1403, 2009.

[17] Jolfaei MG, Sharaf AM, Shariatmadar SM, Poudeh MB. "A hybrid PSS-SSSC GA-stabilization scheme for damping power system small signal oscillations". International Journal of Electrical Power \& Energy Systems, 75, 337-344, 2016.

[18] Elazim SA, Ali ES. "Optimal SSSC design for damping power systems oscillations via Gravitational Search Algorithm". International Journal of Electrical Power \& Energy Systems, 82, 161-168, 2016.

[19] Mohammadzadeh B, Reza G, Rshanagh Sajad NR. "Optimal designing of SSSC based supplementary controller for LFO damping of power system using COA". ECTI Transactions on Electrical Engineering, Electronics and Communications 12(2), 64-72, 2014.
[20] Farsangi MM, Song YH, Lee KY. "Choise of FACTS devices control inputs for damping interarea oscillations". IEEE Transaction on Power Systems, 19(2), 1135-1143, 2004.

[21] Chatterjee D, Ghosh A. "Transient stability assessment of power systems containing series and shunt compensators". IEEE Transaction on Power Systems, 22(3), 1210-1220, 2007.

[22] Haque MH. "Evaluation of first swing stability of large power system with various FACTS devices". IEEE Transaction on Power Systems, 23(3), 1144-1151, 2008.

[23] Radman G, Raje RS. "Dynamic model for power systems with multiple FACTS controllers". Electric Power Systems Research, 78(3), 361-371, 2008.

[24] Sauer PW, Pai MA. Power System Dynamics and Stability. Upper Saddle River, NJ, USA, Prentice-Hall, 1998.

[25] Padiyar KR. Power System Dynamics, Stability and Control. Hyderabad, India, BS Publications, 2002.

[26] Chatterjee D, Ghosh A. "Improvement of transient stability of power systems with STATCOM controller using trajectory sensivity". Electrical Power and Energy Systems, 33(3), 531-539, 2011.

[27] Shakarami MR, Kazemi A. "Assessment of effect of SSSC stabilizer control channels on damping interarea oscillations". Energy Conversion and Management, 52(3), 1622-1629, 2011.

[28] Wang HF. "Modelling multiple FACTS Devices into multi-machine power systems and applications". Electrical Power and Energy Systems, 25(3), 227-237, 2003.

[29] Basaran U. Various Power Flow and Economic Dispatch Analysis on $380 \mathrm{KV}$ Interconnected Power System in Turkey. Master of Science Thesis, Anadolu University, Eskisehir, Turkey, 2004.

[30] Milano, F. "An open source power system analysis toolbox". IEEE Transactions on Power Systems, 20(3), 1199-1206, 2005. 